\title{
Barren Lives: drought shocks and agricultural vulnerability in the Brazilian Semi-Arid - Corrigendum
}

Lucas Costa, André Albuquerque Sant'Anna, and Carlos Eduardo Frickmann Young

https://doi.org/10.1017/S1355770X21000176, Published online by Cambridge University Press: 07 July 2021

When originally published, the article included a spelling mistake in one of the authors' names. The article has now been updated to include the corrected name.

The authors apologize for this error.

\section{Reference}

Costa L, Sant'Anna AA, and Young CEF (2021) Barren lives: drought shocks and agricultural vulnerability in the Brazilian Semi-Arid. Environment and Development Economics, 1-21. https://doi.org/10.1017/ S1355770X21000176

Cite this article: Costa L, Sant'Anna AA, Young CEF (2022). Barren Lives: drought shocks and agricultural vulnerability in the Brazilian Semi-Arid - Corrigendum. Environment and Development Economics 27, 294. https://doi.org/10.1017/S1355770X21000255

(C) The Author(s), 2021. Published by Cambridge University Press 